\title{
eHalal4All Program - Promoting Halal Rural Products and Services Globally by Harnessing the Network-of-Mosques (NoM) Capabilities
}

\author{
Abdul Rahman Ahmad Dahlan ${ }^{1 *}$, Rahmah Ahmad H. Osman ${ }^{2}$, Jamaludin Ibrahim ${ }^{3}$, \\ Mohd Zainudin Othman ${ }^{4}$ \\ ${ }^{1}$ Faculty of Information \& Communication Technology, International Islamic University Malaysia \\ arad@iium.edu.my \\ ${ }^{2}$ Faculty of Islamic Revealed Knowledge \& Human Sciences, International Islamic University Malaysia \\ rahmahao@iium.edu.my \\ ${ }^{3}$ Faculty of Information \& Communication Technology, International Islamic University Malaysia \\ jamaludinibrahim@iium.edu.my \\ ${ }^{4}$ School of Technology Management \& Logistics, University Utara Malaysia \\ zainudin@uum.edu.my \\ *Corresponding Author
}

\begin{abstract}
:
The population of Muslims gobally is estimated to be more than 1.6 billion, which represents about one-fifth of the world's population. The recent religious awakening of Muslims and their realization of the importance of compliance with Shari'ah laws in business dealings have enabled them to achieve their economic and wellbeing goals. This conceptual paper proposes eHalal4All Program, which is to be adopted as one of the 1AZAM Malaysian government-sponsored programs, and implemented as a proof-of-concept in raising the economic and social status of rural communities in Sabah, Malaysia. This program has the potential to enhance wellbeing by providing these rural communities with new skills, machinery, eHalal4All Portal, network of entrepreneurs and Network-of-Mosques (NoM) in generating new sources of income. eHalal4All Program is executed based on the deployment of the Quadruple Helix Model (QHM), where a country's economic structure lies on four actors namely: Government, Academia, Industry, and Citizen, and the economic growth are generated by the clustering and concentration of talented and productive actors. Literature reviews and nine (9) blocks of Business Model Canvas (BMC) framework are used as methodology for this paper. As the extent of rural poverty in Malaysia is expected to be reduced and societal wellbeing to be enhanced through eHalal4All Program, an added benefit is the minimization of the rural-urban migration process. This in turn will result in less pressure on government to provide additional spending on services such as education, provision of clean drinking water and adequate sewage disposal, housing, and health in urban areas as well as having to deal with a host of problems associated with overgrown cities/towns such as a higher incidence of crime and of shanty towns on the outskirts of these cities. Thus, demonstrating the contribution of NoM in realising partly the meaning of "Rahmatan li'l-Alamin".
\end{abstract}

Keywords: 1AZAM, Business Model Canvas, Network-of-Mosques, Quadruple Helix Model, Wellbeing

\section{Introduction}

The population of Muslims gobally is estimated to be more than 1.6 billion, which represents about one-fifth of the world's population. The 11 September 2001 (9/11) event and the recent religious awakening, Muslim entrepreneurs around the world have been increasing seeking to setup businesses that are in compliance with Shari'ah laws whereby enabling them to achieve their economic and wellbeing goals. As one of the Organization of Islamic Countries members, poverty eradication has been the focus and primal priority of the Malaysian Government (Sohag, 2005) where policies, initiatives and programs such as the New Economic Policy (NEP) was implemented. The poverty eradication programs have resulted in drastic reduction in poverty and lessened the income inequality while achieving rapid economic growth and maintaining racial harmony. The NEP from 1970 to 1990 and subsequent policies have markedly reduced poverty in Malaysia, where poverty headcount ratio at national poverty line in Malaysia is reported as follows $3.8 \%$ in $2009,3.6 \%$ in 2007, 5.7\% in 2004, 15.5\% in 1989 (World Bank, 2013). In terms of poverty by state, Sabah has the highest level of poverty and hardcore poverty incidence in Malaysia (EPU, 2012).

The issue of poverty reduction has moved to the next crucial level as the Malaysian government's target is to achieve a high income country by 2020. The eKasih or Sistem Maklumat Kemiskinan Negara is a database system which contains the information on the poor families in Malaysia. The objective of the database system is to help the government in planning, implementing 
and monitoring the "Poverty Eradication" programs. As at January 2011, there were 67,033 (0.82\%) households registered as poor in the eKasih database (Habiba et. al, 2013). Data from eKasih will be used as a base for providing aids or projects' involvement in 1AZAM, another government "Poverty Eradication" program for the poor families. 1AZAM is a key program supported by the Malaysian government, spearheaded by the Ministry of Women, Family and Community Development. 1AZAM stands for "Akhiri Zaman Miskin" in Malay word, but in English is to eradicate poverty, where its main objective is to help the poor citizens with an income of RM830 per month and low-income citizens under RM2,300 a month generating better income. eHalal4All Program is executed based on the deployment of the (a) Quadruple Helix Model (QHM), where a country's economic structure lies on four actors namely: Academia, Industry, Government, and Citizen, and the economic growth are generated by the clustering and concentration of talented and productive actors, (b) "Whole-ofGovernment" (WoG) implementation that demands for a collaborative and co-operative arrangement of open consultation, open data, shared knowledge and expertise, consolidation of shared services and enhanced horizontal application across government agencies; and (c) citizen-centric Network-ofMosques (NoM) - and focusing on achieving a higher quality of life and sustainable prosperity for all poor families in Malaysia.

\section{Program Background}

This paper proposes eHalal4All Program, to be considered and adapted as one of the 1AZAM Malaysian government-sponsored programs in raising the economic and social status of rural community in Sabah, Malaysia. This Program has the potential to reduce poverty and enhance societal wellbeing by providing these rural communities with entrepreneurship skills and machineries in producing, for example, cheap but yet elegant clothes for Muslim women as well as cheap and quality tour services, and promoting these clothes as well as tour services through eHalal4All Portal in generating new sources of income. The 1Azam provides opportunity for poor families to enhance their wellbeing via giving them opportunity in four areas, namely: (1) Azam Kerja for opportunity to generate income through work placement, (2) Azam Tani to generate income based on agriculture, (3) Azam Niaga to generate income through small businesses, and (4) Azam Khidmat to generate income through services (Ministry of Women, Family and Community Development, 2012).

The current and future trend is for consumers to conduct daily on-line transactions including shopping. This on-line trend provides a great opportunity for eHalal4All Portal to advertise its Halal and trusted products/services globally, supported by the Network-of-Mosques. Based on the megatrend study by Frost \& Sullivan (2012), there is a major shift from "Connecting Subscribers to Connecting Devices", where there will be 80 billion of devices connected by 2020 . By 2025, the majority of the world's population will have access to all of the world's content through a device that fits in the palm of the hand. If the current pace of technological innovation is maintained, most of the projected eight billion people on Earth will be online (Eric Schmidt \& Jared Cohen, 2013).

eHalal4All Program, as a proof-of-concept implementation, provides services by harnessing the NoM capabilities in helping the rural community/entrepreneurs in Sabah. The Program provide services including motivation and advisory, training on improving skills \& knowledge, and applying machine/equipment grants from the government Azam Niaga. According to Gerard McElwee \& Andrew Atherton (2011), rural businesses are defined as those occupied on a part or full-time basis and engaged in a range of activities that are primarily dependent on the natural and physical resources of the rural environment as the main source of income and/or utilize local labour to achieve business objectives. This definition includes tourism, food production and processing. Workshops are conducted free-of-charge, and after that these rural communities/entrepreneurs are ready to promote and market their products/services through eHalal4All Portal and NoM. Products/services shall be made and offered only after receiving orders from customers through the Portal.

\section{Problem Statement}

The roles of mosques now are no longer strategic as compared to the time of Prophet Muhammad S.A.W. Spahic Omer (2009) stated that "Apart from being a place for congregational prayers and other collective worship practices, the mosque, likewise, furnished the Muslims with other most vital 
social amenities, it served as the seat of the Prophet Muhammad's government, a learning center, a hospital, a rehabilitation center, a welfare center and the place for some legitimate recreational activities." However, mosques nowadays are mainly used by the community for limited types of religious activities (Mohd Tajuddin, 1999). To revive and reinvigorate the strategic roles which mosques used to play, contemporary implementation concepts used by the Malaysian government such as QHM, WoG and Rural Entrepreneurship via 1AZAM/eKasih together with the ICT-based capabilities such as ubiquitous and Cloud computing need to be leveraged and deployed.

\section{Program Objectives}

The main objective of eHalal4All Program is to harness (a) the Malaysian governmentsponsored poverty eradication programs, namely $1 \mathrm{AZAM} / \mathrm{eKasih}$ that is spearheaded by the Ministry of Women, Family and Community Development (MWFCD), and (b) the network of mosques $(\mathrm{NoM})$. This Program is executed based on the deployment of the (a) Quadruple Helix Model (QHM), where a country's economic growth are generated by the clustering and concentration of talented and productive actors namely: Academia, Industry, Government, and Citizen, and, (b) "Whole-ofGovernment" (WoG) implementation that demands for a collaborative and co-operative arrangement of open consultation, open data, shared knowledge and expertise, consolidation of shared services and enhanced horizontal application across government agencies; and (c) citizen-centric Network-ofMosques (NoM) - and focusing on achieving a higher quality of life and sustainable prosperity for poor families. Sabah, with the highest level of poverty and hardcore poverty incidences in Malaysia is chosen as Proof-of-Concept for this proposed eHalal4All Program implementation.

As the extent of rural poverty in Sabah is expected to be reduced and societal wellbeing to be further enhanced through eHalal4All Program, an added benefit is the minimization of the rural-urban migration process. This in turn will result in less pressure on government to make provision for additional spending on services such as education, provision of clean drinking water and adequate sewage disposal, housing, and health in urban areas as well as having to deal with a host of problems associated with overgrown cities/towns such as a higher incidence of crime and of shanty towns on the outskirts of these cities. At the same time, there is a need for an effective program mamangement (Handayani et. al, 2010) and change management program (Ammy Amelia Faisal et. al, 2013; Cutifa Safitri et. al, 2013; Fatima Munassar et. al, 2013; Alyaa Ghani et. al, 2013; Azarian \& Dahlan, 2014) to make eHalal4All Program, which demands QHM and WoG collaboration, a success.

\section{Literature Review}

Several factors have been contributing to the recent growing interest amongst Muslim enterpreneurs around the world in setting up enterprises that are consistent with Shariah law, which will enable them to achieve their economic goals and religious obligations. According to Wafica Ali Ghoul (2011), these factors include:

- The recent surge in oil prices which has created excess liquidity in the Muslim world.

- The events of 11 September 2001 (9/11) in the USA, which led many Muslims to repatriate their money back home for fear of new Western regulations that resulted in increased scrutiny combined with a backlash against Muslims around the world, both real and perceived.

- The high population growth rate in Muslim countries, currently estimated to be 1.6 billion Muslims, means that the target audience for Muslims enterprises is significant and growing.

- The recent religious awakening of Muslims and their realization of the importance of compliance with Shari' ah rules and principles in their business dealings.

- High unemployment rates, internal conflicts, wars with neighboring countries, poverty, gender issues, as well as political oppression currently plague most of the Muslim countries. Consequently, the number of Muslims who are choosing to immigrate to the Western world (particularly North America and Europe) has been growing, which necessitates the establishment of Muslim enterprises in Muslim immigrant communities. 
- There is an anticipated growth of interest by non-Muslim clients who have been seeking socially responsible and ethical products and services, which would contribute to sustaining the growth of Muslim enterprises.

There were discussions among the scholars regarding the Mosque having strategic roles during the time of Prophet Muhammad S.A.W. (Mohd Mokhtar, 2003; Ab. Halim et. al, 2003; Abd. Shukor, 2009). The prophet's Mosque was seen as the ultimate center for the Muslim community where key activities including social, economy, political, and educational were conducted. Moreover, after Prophet S.A.W, especially during the Abbasid Caliphate has shown many evidences as Halaqah Al-Ta'lim (study circles) have taken places in mosques. Spahic Omer (2009) has argued that: "The mosque institution was set to be introduced at once as a nucleus of the believers' existence and an epitome of the inexhaustible struggle between good and evil on the earth. Apart from being a place for congregational prayers and other collective worship practices, the mosque, likewise, furnished the Muslims with other most vital social amenities, it served as the seat of the Prophet Muhammad's government, a learning center, a hospital, a rehabilitation center, a welfare center and the place for some legitimate recreational activities."

As in Malaysia, the 1AZAM program was introduced by the government to eradicate and reduce poverty rate by providing employment and/or entrepreneurship to the nation's hardcore poor and poor citizens. "The concept of entrepreneurship as defined by Casson (1985) is the management of resources which is essential in controlling wealth, not unlimited resources controlling wealth" (Mohd. Taib Dora, 2011). This 1AZAM program aims to enhance wealth creation, exceeding the poverty limits of RM830 per month for the poor and under RM2,300 a month for low-income earners. 1AZAM is being conducted nationwide in stages. The pilot program was initiated in the Iskandar Regional Development Authority or Iskandar Malaysia, Johor, at the end of January 2010.

Based on The New Straits Times (NST, 14/6/2012), the Prime Minister of Malaysia has said that the involvement of 80,579 people in the 1Azam programme shows its effectiveness as a strategic effort by the government to eradicate poverty. In another statement by the Women, Family and Community Development Minister, 1Azam programme has recorded a reduction of $55.3 \%$ of the national poverty rate (NST, 24/9/2013). From 2010 until the end of last year, 65.65\% of the 106,967 1Azam programme participants comprised women. The 1AZAM programme has so far trained and created 4,300 women entrepreneurs, with $86.86 \%$ of them comprising Bumiputera (NST, 13/9/2013). Sources from the Asian Development Bank conference said the national poverty rate has dropped from $3.8 \%$ in 2009 to $1.7 \%$ in 2012.

The current and future trend is for people to conduct daily on-line transactions including shopping. Based on the mega-trend study by Frost \& Sullivan (2012), there is a major shift from "Connecting Subscribers to Connecting Devices", where there will be 80 billion of devices are connected by 2020. By 2025, the majority of the world's population will have access to all of the world's content through a device that fits in the palm of the hand. According to Eric Schmidt and Jared Cohen (2013), if the current pace of technological innovation is maintained, most of the projected eight billion people on Earth will be online including in the developing countries. Through Internet, age old limitations to human interaction, like geography, language, and limited \& controlled information, are falling and a new wave of human creativity, innovation and potential is rising. Mass adoption of the Internet is driving one of the most exciting social, cultural and political transformations in history, and unlike earlier periods of change, this time the effects are fully global. Never before in history have so many people, from so many places, had so much power at their fingertips. And while this is hardly the first technology revolution in our history, it is the first that will make it possible for almost everybody to own, develop and disseminate real-time content without having to rely on intermediaries.

\section{Proposed Conceptual Solution}

In focusing to eHalal4All Portal, it will make use of the Internet to provide a user-friendly, engaging and attractive portal with many useful functionality and features. "The Internet is a technology that they use to communicate, collaborate, and share databases, information and knowledge in creating values and improve societal well-being" (Burhan Saleh et. al, 2013). It will include usability and navigation, usable form, secondary call-to action, social button and contact info. 
Customers book products and/or services that can be customised by completing the provided usable form on the Portal. All needed information and customer details will be included in the usable form. For an example, this Portal will provide samples of products that are available on KAMDAR Fabric Company. When a customer clicks on the sample's picture, the secondary call-to-action button will appear and provide the customer with details on the fabrics such as design, size, colour, price and availability. Hence, the customer does not have to deliver the fabric by hand to the tailor just like the traditional tailoring. It also saves the customer delivering fees because she does not have to post their own fabric to the tailor just like the current e-tailor such as Kedai JahitKu. In order to protect the tailor rights and to avoid cancelation of order by the customer, the customer will be required to pay in advance. The advanced payment will also assist the tailor in buying the selected fabric.

As part of advertisement, eHalal4All Portal shall embed social network buttons such as Facebook and Twitter. Hence, customers can share eHalal4All Portal in their social network. In order to attract more on-line visitors, eHalal4All Portal shall be linked to other popular blogs, portals and websites. eHalal4All Portal has advantages over the traditional tailoring businesses, namely in terms of global reach and wider range of customers. The eHalal4All Portal surpasses the existing e-tailor business models, by providing customers with various choices of unsewn fabric, whilst simultaneously saving customers' time for buying the fabrics as well as lower delivering costs. In addition, eHalal4All Portal provides a free membership and platform for the Community of Practice $(\mathrm{CoP})$ in various domains.

Figure 1 shows the 9 blocks of Business Canvas Model (BMC) of eHalal4All Portal in Sabah. The 9 blocks of BMC are value proposition, customer segment, customer relationship, channel, key activities, key resources, key partners, course structure and revenue streams which based on Alexander Osterwalder (2010).

Figure 1 : Business Model Canvas (BMC) for e-Halal4All Program

\section{The Business Model Canvas}

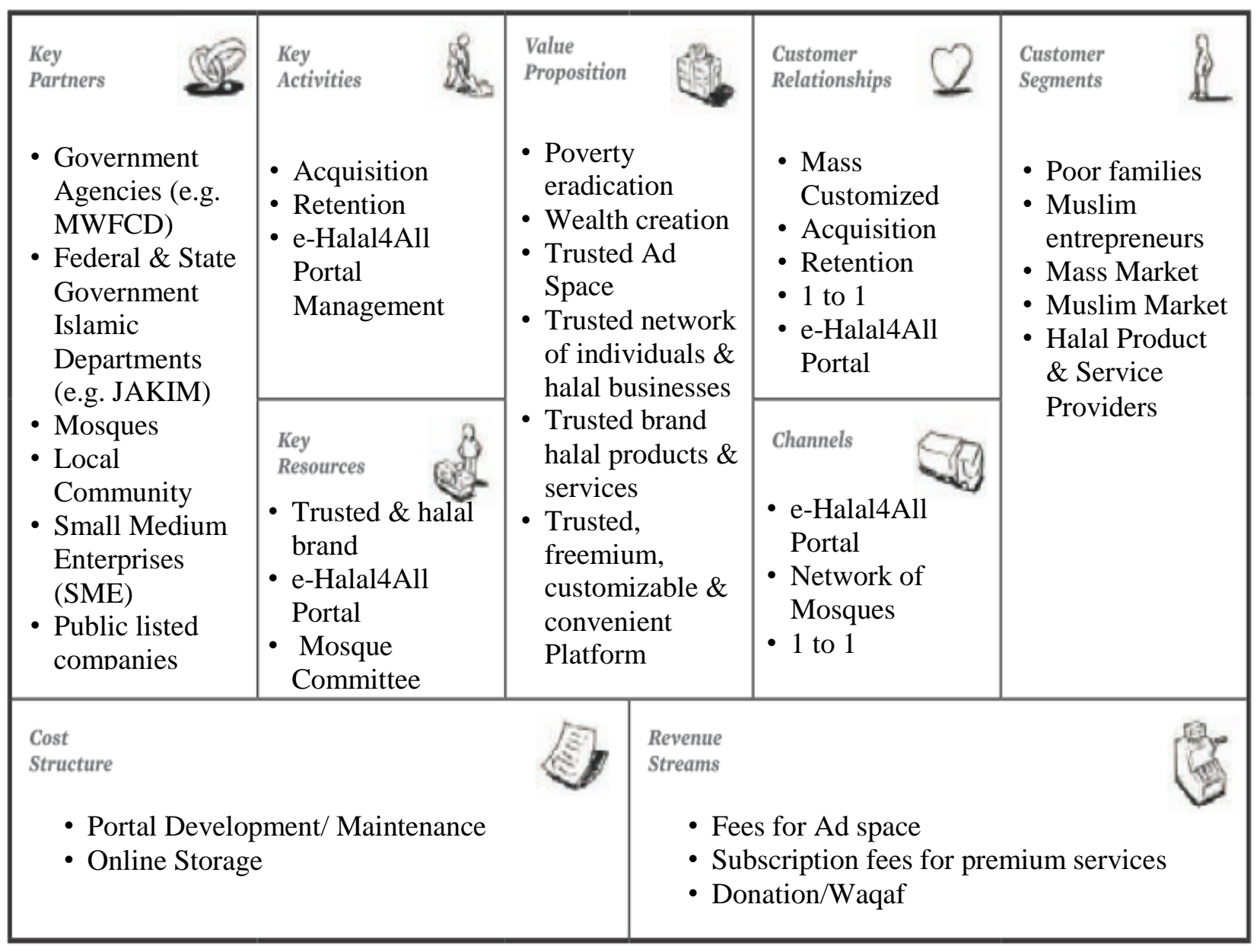




\subsection{Value Preposition}

The Value Propositions Building Block describes the value in which the bundle of products and services that eHalal4All Program create for Customer Segments. This includes:

- Trusted, freemium and convenient platform advertisement of halal products and services entrepreneurs/providers as well as offerings.

- Trusted entrepreneur's database.

- Trusted individuals database as potential customers.

- Trusted physical and virtual channels for global market reach.

\subsection{Customer Segments}

The Customer Segments Building Block defines the different groups of people or organizations eHalal4All Portal aims to reach and serve. The focus customer segments are:

- The first customer segment is halal product and service entrepreneurs/providers.

- The second segment is the on-line shoppers, initially focusing on Malaysian Muslims.

- Poor families and Muslim entrepreneurs.

\subsection{Customer Relationship}

The Customer Relationships Building Block describes the types of relationships eHalal4All Program establishes with specific Customer Segments. There are two types of customer relationships. The main aim is to acquire, retain, develop (a) entrepreneurs/providers, and (b) customers/buyers physically as well as virtually.

\subsection{Channels}

The Channels Building Block describes how eHalal4All Program communicates with and reaches its Customer Segments to deliver the Value Proposition. The main channels include:

- eHalal4All Portal - an attractive, engaging, and user-friendly portal incorporating social network buttons for easy sharing of functionality. Entrepreneurs/providers can upload latest products and services offerings. Customers can get the latest information easily through the Net and mobile devices. The Portal is link to other popular websites, portals and blogs with purpose, activities, products and services offering.

- Network-of-Mosques (NoM) - The NoM members, digitally connected, function as the avenue in capturing and updating data on the poor families as well as encouraging active entrepreneurs/providers in Government-led "Poverty Eradication" programs such as 1AZAM/eKasih (Habiba et. al, 2013).

- Face-to-face - The experts are able to further develop the skill of entrepreneurs/providers face-to-face as well as virtually.

\subsection{Revenue Streams}

The Revenue Streams Building Block represents the cash eHalal4All Program generates from each Customer Segment (costs must be subtracted from revenues to create earnings). This includes:

- Provision from sponsors through government tax exemption of companies' contribution and involvement in eHalal4All Program.

- Advertising fees through eHalal4All Portal.

- Subscription fees of entrepreneurs and individuals.

- No fees for entrepreneurs from eKasih database (i.e. poor families).

- Donation and waqaf.

\subsection{Key Partners}

The Key Partnerships Building Block describes the network of suppliers and partners that make the eHalal4All Program work. The key partners include:

- Quadruple Helix Model (QHM) collaborators namely the Government, Academia, Industry, and Citizen. 
- The Ministry of Women, Family and Community Development, the owner of 1AZAM program - AZAM Niaga scheme to generate income through small business.

- Industry - companies that collaborate with the government to provide the machinery and expertise under their Corporate Social Responsibility (CSR) programs.

- Academia - Expertise and volunteers from staff and students.

- Islamic departments at national and state levels e.g. JAKIM - ensuring network of mosques and mosques committees provide the commitment and support.

\subsection{Key Activities}

The Key Activities Building Block describes the most important things eHalal4All Program must do to make its business model work. The key activities include:

- Acquisition and retention of buyer-type of customers physically and virtually.

- Acquisition, retention and development of entrepreneur-type of customers. Likewise, workshops and tutorials by experts are provided physically and virtually. eHalal4All Portal creates an online presence, community of practice (CoP), and marketplace for entrepreneurs so that they can contribute and sell their expertise and services.

\subsection{Key Resources}

The Key Resources Building Block describes the most important assets required to make eHalal4All Program work. The key resources include:

- Machineries from 1AZAM program - executed based on the deployment of the Quadruple Helix Model (QHM) collaboration. Industry will get tax exception for its contributions of resources in CSR programs.

- Government agencies through "Whole-of-Government" (WoG) implementation.

- Citizen-centric Network-of-Mosques (NoM) and mosques committees.

- Universities - supply of expertise and volunteers in knowledge and technology transfer to the communities through eHalal4All Program.

- eHalal4All Portal.

\subsection{Cost Structure}

The Cost Structure describes all costs incurred to operate eHalal4All Program which include:

- Rental of cloud services and maintenance of eHalal4All Portal

- Allowances for volunteers

\section{Conclusion and Future Works}

In conclusion, this paper proposes eHalal4All Program aim to raising the economic and social status of rural communities/entrepreneurs in Sabah, Malaysia. The Quadruple Helix Model (QHM) implementation of eHalal4All Program to be considered and adapted by the Ministry of Women, Family and Community Development (MWFCD), with close collaboration with the Government, Academia, Industry, and Citizen actors. The economic growth and poverty eradication are done by the clustering and concentration of talented and productive of the 4 actors, spearheaded by MWFCD as the owner of 1AZAM program and JAKIM/JAIN as the lead agency for Network-of-Mosques (NoM).

If this PoC implementation is successful in Sabah, eHalal4All Program can be considered for national roll-out to benefit more poor families and rural entrepreneurs. And later would be implemented world-wide for poverty eradication and wealth creation initiatives. Simultaneously, continuous monitoring of implementation and operations of eHalal4All Program need to be conducted including visitations. This is to avoid embarrassing situations happening such as: "KUCHING: There is no denying that many 1Azam participants have sold off equipment given to them by the government to help them get out of poverty." (Borneo Post Online, 2014, 1Azam programme surpasses 7,500-participant target). Furthermore, continuous skills upgrading, new and contemporary products designs offerings, global advertising/promotions need to be studied and coordinated.

This eHalal4All Program has the potential to reduce poverty in Sabah by providing with skills, machineries, and eHalal4All Portal in generating new sources of income. As the extent of rural 
poverty in Sabah is expected to be reduced and societal wellbeing to be enhanced through eHalal4All Program, an added benefit is the minimization of the rural-urban migration process. This in turn will result in less pressure on government to make provision for additional budget on services such as education, provision of clean drinking water, adequate sewage disposal, housing, and health in urban areas as well as having to deal with a host of problems associated with overgrown cities/towns. The MWFCD and JAKIM/JAIN need to provide the leadership role, in close collaboration with other QHM key actors leveraging and harnessing on the Network of Mosques (NoM) capabilities, for the success of eHalal4All Program. This Program is to be implemented together with an effective and holistic project and change management program.

\section{References}

1Azam records 55.3\% cut in national poverty rate (2013). Retrieved Tuesday, March 04, 2014, from: http://www.nst.com.my/latest/1azam-records-55-3pc-cut-in-national-poverty-rate-1.362321

1Azam programme has created 4,300 women entrepreneurs (2013). Retrieved Tuesday, March 04, 2014, from: http://www.nst.com.my/nation/general/1azam-programme-has-created-4-300women-entrepreneurs-1.355274

1Azam programme surpasses 7,500-participant target (January 9, 2014, Thursday). Retrieved Wednesday, March 12, 2014, from: http://www.theborneopost.com/2014/01/09/1azamprogramme-surpasses-7500-participant-target/

Ab. Halim Tamuri, Shahrin Awaluddin and Tajul Ariffin Noordin, (2003). "Fungsi surau dan keberkesanannya dalam pengajaran dan pembelajaran pendidikan Islam: satu kajian di sekolahsekolah menengah negeri Selangor". Laporan Penyelidikan. Bangi: Fakulti Pendidikan, Universiti Kebangsaan Malaysia.

Abd. Shukor Mohd Ali, (2009). "Modul pengajaran dan pembelajaran pendidikan Islam berasaskan masjid: satu kajian di Sekolah Berasrama Penuh Integrasi Rawang, Bandar Tasik Putri, Rawang, Selangor". Research Project Master of Education. UKM Bangi.

Alexander Osterwalder (2010). Business handbook for Visionaries, Game Changers, and Challengers", John Wiley, New Jersey, USA.

Alyaa Ghanim, Fatima Munassar, Abdul Rahman Ahmad Dahlan (2013). "Project and Change Management Success Factors from Malaysian Government Departments and Agencies Perspective", IOSR Journal of Business and Management Vol. 11, No 2, pp. 36-45

Ammy Amelia Faisal, Cutifa Safitri, Abdul Rahman Ahmad Dahlan (2013). "Value-Driven Approach for Project Success and Change Management in Malaysian Institutions of Higher Learning (IHL)", International Journal of Science and Research, Volume 2 Issue 6, June 2013

Azarian, M. S., Dahlan, A.R.A. (2014) "An Empirical Analysis Of Knowledge Management's Role Towards Achieving Success In The Malaysian Government Agencies", Proceeding of Knowledge Management International Conference (KMICe) 2014, pp. 446-452

Blog of Ruang berkongsi "cerita" dan "ilmu jahitan" (2011). Retrieved Wednesday, March 12, 2014, 4:18 PM from: http://kedaijahitku-jahit.blogspot.com/p/kedai-jahit.html?m=1)

Burhan Saleh, Nalinee Ma-Key, Abdul Rahman Ahmad Dahlan, Rahmah Ahmad H.Osman (2013). "MyMukim2Cloud Collaborative System A Mosque Collaborative Network for Serving the Societal Needs in Malaysia", IEEE, 5th International Conference on Information and Communication Technology for the Muslim World 2013.

Cutifa Safitri, Ammy Amelia Faisal, Abdul Rahman Ahmad Dahlan (2013). "Success Factors and Change Management in Malaysian Institutions of Higher Learning (IHL)", International Journal of Science and Research, Volume 2 Issue 6, June 2013

Eric Schmidt and Jared Cohen (2013). "The New Digital Age: Reshaping the Future of People, Nations and Business", Random House, Inc., New York.

EPU - Economic Planning Unit, Prime Minister's Department of Malaysia (2012). "Incidence of Poverty by Ethnicity, Strata and State, Malaysia, 1970-2012”. Retrieved March 04, 2014, from http://www.epu.gov.my/en/household-income-poverty

Fatima Munassar, Alyaa Ghanim, Abdul Rahman Ahmad Dahlan (2013). "Change Management and its Contribution to the Success of IT Project Implementation", International Journal of Information and Communication Technology Research, Volume 3 No. 4, April 2013 
Gerard McElwee \& Andrew Atherton (2011). "Rural entrepreneurship". In Leo-Paul Dana (Ed.) "World Encyclopedia of Entrepreneurship" pp. 377-384. Massachusetts: Edward Elgar Publishing

Habiba Hamid, Nur Dini Khairuddin, Yousra Al-amodi, Abdul Rahman Ahmad Dahlan, Rahmah Ahmad H. Osman (2013). "MyMosqueNet2Cloud Collaborative System: A network of mosques towards eradicating poverty in Malaysia", American Academic \& Scholarly Research Journal, Vol. 5, No. 5, pp. 169-179.

Handayani D., Abdullah R.B., Abdulgani M.A., Dahlan A.R.A (2010). "Critical success factors for IS project implementation in Malaysian institutions of higher learning", IEEE, 3rd International Conference on Information and Communication Technology for the Muslim World: ICT Connecting Cultures, ICT4M 2010

Jenis Azam. Retrieved Wednesday, March 05, 2014, from: http://www.kpwkm.gov.my/jenis-azam

Ministry of Women, Family and Community Development (2012). Program 1Azam. Retrieved March 04, 2014, from: http://www.kpwkm.gov.my/nkra/1azam

Mohammad Tajuddin Mohammad Rasdi, (1998). "The mosque as a community development centre". Skudai: Penerbit UTM.

Mohd. Mokhtar Shafi, (2003). "Masjid Sebagai Pusat Pendidikan dan Penjaminan Ummah Cermerlang", Jurnal Pendidikan Islam 10. Bil 3. Selangor: Kolej Dar Al-Hikmah.

Mohd. Taib Hj. Dora (2011). Eradicate Urban Poverty in Malaysia through Entrepreneurship Strategies. International Journal of Humanities and Social Science, 1(20), Centre For Languages and Human Development, Universiti Teknikal Malaysia Melaka

PM: 1 Azam programme effective in eradicating poverty (2012). Retrieved March 04, 2014, from: http://www.nst.com.my/nation/general/pm-1-azam-programme-effective-in-eradicatingpoverty-1.94640

Sohag, K (2005). "Reducing Poverty through Zakat System": Research Paper written as Partial Fulfillment for the Course Eco 490- Research Methodology, Submitted to Dr. Amir Hussaint, Adjunct Professor Department of Economics, East West University, retrieved March 04, 2014, from: http://www.scribd.com/doc/3176458/poverty-reduce-through-zakat-by-sohag

Spahic Omer, (2009). "The history and character of the Islamic built environment". Selangor: Arah Publication.

Wafica Ali Ghoul (2011). "Islam and entrepreneurship". In Leo-Paul Dana (Ed.) "World Encyclopedia of Entrepreneurship" pp. 293-301. Massachusetts: Edward Elgar Publishing 